\title{
Analisis Evaluasi E-Learning Menggunakan Integrasi Model D\&M dan UTAUT
}

\author{
Integration of D\&M and UTAUT Model to Analyze the Result of \\ E-Learning Evaluation \\ Kadek Dwi Pradnyani Novianti \\ STMIK STIKOM Bali; Jalan Raya Puputan Renon No 86 \\ Program Studi Sistem Informasi, STMIK STIKOM Bali, Denpasar \\ e-mail: novianti@stikom-bali.ac.id
}

\begin{abstract}
Abstrak
E-learning merupakan media dalam proses pembelajaran yang memanfaatkan teknologi untuk pendidik dan peserta didik sehingga memudahkan proses pembelajaran. Sebagai sebuah sistem informasi yang sering digunakan oleh peserta didik, e-learning harus memiliki standar tertentu. Penelitian ini bertujuan untuk mengetahui hasil evaluasi kesuksesan e-learning dan penerimaannya di kalangan peserta didik pada STIKOM Bali. Penelitian ini menggunakan model DeLone \&McLean (D\&M) untuk mengukur tingkat kesuksesan sistem informasi dan model Unified Theory of Acceptance and Use of Technology (UTAUT) untuk mengukur tingkat penerimaan teknologi. Agar dapat mengetahui hasil evaluasi antara kesuksesan sistem informasi dan penerimaan teknologi untuk maka kedua model ini kemudian diintegrasikan untuk mencapai tujuan penelitian. Kedua model ini dapat menggambarkan bagaimana masingmasing variabel pengukuran saling mempengaruhi satu sama lain, sehingga keterkaitan antar variabelnya dapat diketahui. Selain itu kedua model ini mempertimbangkan bagaimana perilaku pengguna ketika menggunakan sebuah sistem informasi. Hasil menunjukan bahwa penerimaan pengguna terhadap penerapan e-learning menyebabkan sebuah informasi sukses diterapkan dalam lingkungannya. Hal ini dapat dilihat dari model penelitian yang diajukan menunjukan sebagian besar variabelnya mempengaruhi kesuksesan penerapan e-learning baik secara langsung maupun tidak langsung. Variabel-variabel tersebut adalah performance quality, effort expectancy, system quality, behavioral intention, dan user satisfaction.
\end{abstract}

Kata kunci- e-learning, D\&M, UTAUT

\begin{abstract}
E-learning is a technology for educators and students to facilitate the learning process. As an information system that is often used by students, e-learning must have certain standards. This study aims to evaluating the rate of e-learning successfulness and acceptance rate among students at STIKOM Bali. This study uses the DeLone \& McLean (D \& M) model to measure the success rate of information systems and the Unified Theory of Acceptance and Use of Technology (UTAUT) model to measure the level of technology acceptance. Those two models were combined to achieve the research objectives. Both of these models can illustrate how each measurement variable influences each other, so that the interrelationships between variables can be known. In addition, both of these models consider how user behavior when using an information system. The results show that user acceptance of the application of e-learning causes a successful information to be applied in its environment. This can be seen from the proposed research model showing that most of the variables affect the success of the application of e-learning both directly and indirectly. These variables are quality performance, effort expectancy, system quality, behavioral intention, and user satisfaction.
\end{abstract}

Keywords-e-learning, D\&M, UTATUT 


\section{PENDAHULUAN}

E-learning merupakan salah satu penerapan sistem informasi yang dimanfaatkan dalam proses pembelajaran bagi pendidik dan peserta didik. Peserta didik diharapkan dapat belajar secara mandiri melalui e-learning di luar pertemuan yang dilakukan di kelas. Pemanfaatan elearning ini dilakukan untuk mengubah model pembelajaran menjadi lebih baik dan menggerakan proses pembelajaran ke arah digital, baik dari isi pembelajaran maupun sistem pembelajaran yang diterapkan [1][2]. Interaksi antara pendidik dan peserta didik terhadap penggunaan e-learning menjadi objek interaksi yang tidak terpisahkan. Pengguna merupakan penentu utama sebuah e-learning apakah layak atau tidak untuk digunakan. Sebuah e-learning dapat dikatakan sukses apabila factor kualitas sistem dan kualitas informasi yang dihasilkan oleh e-learning mampu memberikan rasa puas terhadap pengguna. Kepuasaan pengguna dapat ditunjukan melalui kesediaan pengguna untuk menerima serta menggunakan e-learning hingga akhirnya e-learning dapat meningkatkan kinerja pengguna.

Penggunaan yang berulang-ulang oleh pendidik dan peserta didik menyebabkan elearning haruslah memiliki kualitas sistem dan informasi yang baik. DeLone \& McLean (D\&M) merupakan sebuah model yang sering digunakan untuk mengevaluasi kualitas sebuah elearning. Representasi dari model D\&M adalah kualitas sistem (system quality), kualitas output (information quality), penggunaan output (use), respon pengguna terhadap sistem (user satisfaction), pengaruh sistem informasi terhadap kinerja pengguna (individual impact), dan pengaruh terhadap kinerja organisasi (organizational impact) [3]. Arifin dan Pratolo menggunakan model ini untuk mengevaluasi Sistem Informasi Keuangan Daerah (SIKD) dimana hasil yang diperoleh menunjukan bahwa kualitas SIKD tidak memiliki pengaruh yang signifikan terhadap kepuasan aparatur pemerintah daerah. Begitu juga kepuasan aparatur pemerintah daerah tidak berpengaruh terhadap dampak individual penggunaan sistem informasi [4].

Disamping melihat kesuksesan dari penerapan e-learning, evaluasi lain yang dapat dilakukan adalah terkait dengan penerimaan pengguna terhadap sebuah e-learning. Model evaluasi untuk penerimaan teknologi oleh pengguna adalah Unified Theory of Acceptance and Use of Technology (UTAUT). UTAUT merupakan penggabungan dari delapan teori terkemuka yaitu Theory Of Reasoned Action (TRA), Technology Acceptance Model (TAM), Motivational Model (MM), Theory Of Planned Behavior (TPB), combined TAM and TPB, Model Of PC Utilization (MPTU), Innovation Diffusion Theory (IDT), dan Social Cognitive Theory (SCT). UTAUT memiliki tujuan untuk memahami bagaimana pengguna bereaksi terhadap pengenalan teknologi baru. Reaksi dan persepsi pengguna akan memiliki pengaruh terhadap sikapnya untuk menerima teknologi tersebut [5]. Disebutkan juga bahwa UTAUT penggunaan UTAUT untuk mengetahui penerimaan teknologi dikarenakan model ini merupakan pembaharuan yang berasal dari hasil sintesa konstruk-konstruk pada model penerimaan sebelumnya yaitu TRA, TPB, TAM, dan MPCU [6]. UTAUT juga banyak diadopsi untuk mengetahui penerimaan teknologi yang digunakan baik dalam bidang Pendidikan ataupun pemerintahan. Bendi dan Andayani menggunakan adopsi model UTAUT untuk melihat niat pengguna SIAk di STT Musi dan STIE Musi. Empat konstruk dari UTAUT digunakan sebagai determinan yang mempengaruhi niat pengguna (behavioral intention), yaitu: performance expectancy, effort expectancy, social influence dan facilitating conditions. Hasil yang diperoleh menunjukkan bahwa behavioral intention secara signifikan dipengaruhi oleh performance expectancy, effort expectancy dan facilitating conditions, sedangkan faktor social influence tidak memiliki pengaruh secara signifikan [7].

Berdasarkan pemaparan diatas, akan dilakukan evaluasi terhadap e-learning pada STMIK STIKOM Bali menggunakan integrasi kedua model yang telah dipaparkan yaitu D\&M dan UTAUT. Kedua model ini digunakan untuk evaluasi karena model-model ini mampu menggambarkan bagaimana masing-masing variabel pengukuran saling memberikan pengaruh satu sama lain, sehingga keterkaitannya dapat diketahui hubungannya. Selain itu, model D\&M dan UTAUT mempertimbangkan bagaimana perilaku pengguna ketika menggunakan e- 
learning. Pertimbangan terhadap perilaku pengguna pada model-model tersebut diharapkan dapat menggambarkan hasil evaluasi terhadap kesuksesan implementasi e-learning dilihat dari penerimaan pengguna terhadap e-learning tersebut.

\section{METODE PENELITIAN}

Metode penelitian yang digunakan dalam penelitian ini adalah integrasi model D\&M dan model UTAUT. Integrasi model [8] dilakukan dengan mengkombinasikan setiap komponen yang terlibat sehingga mampu menggambarkan variabel yang diukur yaitu kesuksesan elearning dan penerimaan pengguna. Maka hasil integrasi dari Model D\&M dan UTAUT menghasilkan 6 variabel bebas (performance quality, effort expectancy, system quality, dan social quality) yang mempengaruhi 2 variabel terikat (Use Behavior dan Net Benefit) seperti pada Gambar 1. Adapun variabel-variabel yang digunakan untuk evaluasi antara lain sebagai berikut.

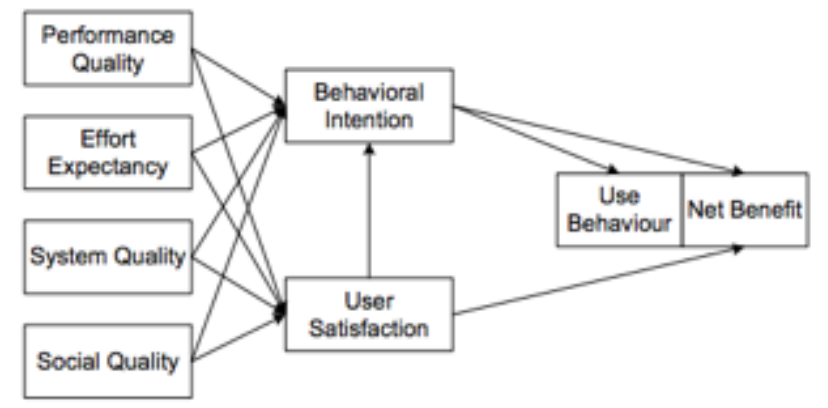

Gambar 1 Model Penelitian

1. Performance Quality (PQ)

Digunakan untuk mengukur sejauh mana pengguna percaya mengenai manfaat e-learning untuk membantu meningkatkan kinerjanya.

2. Effort Expectancy (EE)

Digunakan untuk mengukur kemudahan penggunaan e-learning.

3. System Quality (SyQ)

Digunakan untuk mengukur karakteristik dari kualitas e-learning.

4. Social Quality (SoQ)

Digunakan untuk mengukur sejauh mana pengguna meyakini bahwa ia harus menggunakan e-learning yang ada.

5. Behavioral Intention (BI)

Digunakan untuk ukuran kekuatan niat seseorang untuk melakukan perilaku pengguna ketika menggunakan e-learning.

6. User Satisfaction (US)

Digunakan untuk mengukur respon terhadap kepuasaan pengguna terhadap e-learning.

7. Use Behaviour (UB)

Digunakan untuk mengukur bagaimana perilaku pengguna ketika menggunakan e-learning.

8. Net Benefit (NB)

Digunakan untuk mengukur dampak kesuksesan penggunaan e-learning terhadap organisasi ataupun pengguna.

\section{HASIL DAN PEMBAHASAN}

\subsection{Kuisioner Penelitian}

Kuisioner penelitian yang akan digunakan untuk mengukur variabel-variabel penelitian pada research model dapat dilihat pada Tabel 1 . Kuisioner terdiri dari 25 pertanyaan yang 
mendeskripsikan masing-masing variabel. Kuisioner akan disajikan menggunakan Skala Likert dengan penilaian sebagai berikut.

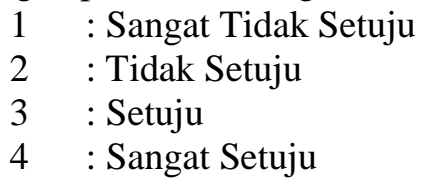

Data Kuisioner yang dikumpulkan dalam penelitian ini diukur dari jawaban langsung responden dengan jumlah 98 mahasiswa.

Tabel 1 Kuisioner Penelitian

\begin{tabular}{|l|}
\hline Variabel Performance Quality \\
\hline 1. E-learning STIKOM Bali berguna untuk studi saya \\
2. E-learning memungkinkan saya untuk mengakses materi mata kuliah dengan cepat \\
3. E-learning STIKOM Bali meningkatkan produktivitas untuk mengerjakan dan \\
mengumpulkan tugas kuliah \\
4. E-learning STIKOM Bali sangat membantu saya untuk mendapatkan nilai yang baik \\
\hline Variabel Effort Expectancy \\
\hline 1. Saya memahami cara mengakses dan menggunakan e-learning STIKOM Bali \\
2. Saya dengan sangat mudah menggunakan fitur-fitur dalam e-learning STIKOM Bali \\
3. E-learning STIKOM Bali menggunakan Bahasa yang dapat dengan mudah saya \\
pahami \\
Variabel System Quality
\end{tabular}

1. Saya dapat menggunakan e-learning STIKOM Bali dan merubah data yang tersedia sesuai dengan kebutuhan perkuliahan

2. Informasi perkuliahan (jadwal perkuliahan dan dosen pengajar) pada e-learning STIKOM Bali sesuai dengan sistem lainnya yang digunakan oleh mahasiswa (SION)

3. Saya tidak perlu waktu lama untuk mendapatkan informasi perkuliahan setelah mengakses e-learning STIKOM Bali

4. E-learning STIKOM Bali memberikan fasilitas perbaikan jika terjadi kegagalan sistem

\section{Variabel Social Quality}

1. Rekan mahasiswa saya mempengaruhi saya dalam penggunaan e-learning STIKOM Bali

2. Dosen pengajar membantu/mendorong saya untuk menggunakan e-learning STIKOM Bali

3. Secara umum STIKOM mendukung penggunaan e-learning STIKOM Bali (misal: dengan menyediakan komputer, akses internet)

\section{Variabel Behavioural Intention}

1. Saya berniat menggunakan e-learning STIKOM Bali di semester berikutnya

2. Saya memperkirakan bahwa saya akan menggunakan e-learning STIKOM Bali di semester berikutnya

3. Saya berencana menggunakan e-learning STIKOM Bali di semester berikutnya

\section{Variabel User Satisfaction}

1. Saya puas dengan data materi kuliah dan informasi pengumuman yang terdapat di elearning STIKOM Bali

2. Saya puas dengan performa e-learning STIKOM Bali

\section{Variabel Use Behaviour}

1. Dalam sehari saya pasti mengakses $e$-learning STIKOM Bali

2. Selama mengikuti perkuliahan, saya sering mengakses $e$-learning STIKOM Bali Variabel Net Benefit

1. Saya dapat menyelesaikan tugas atau quiz lebih cepat dengan menggunakan $e$ learning STIKOM Bali 


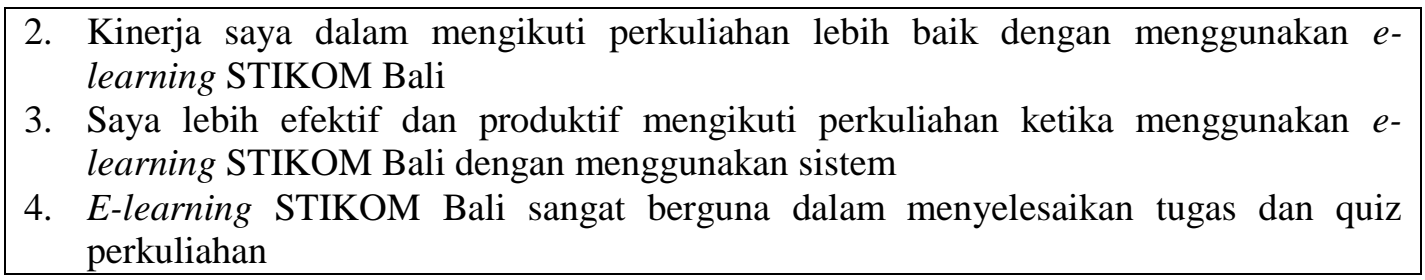

\subsection{Hipotesis Penelitian}

Dari integrasi Model UTAUT dan Model DeLone \& McLean yang telah dipaparkan dalam model penelitian maka diperoleh hipotesis sebagai berikut.

$\begin{array}{ll}\text { H1a } & \text { : Performance Quality berpengaruh postif dan signifikan terhadap Behavioral Intention } \\ \text { H1b } & \text { : Performance Quality berpengaruh positif dan signifikan terhadap User Satisfaction } \\ \text { H2a } & \text { : Effort Expectancy berpengaruh postif dan signifikan terhadap Behavioral Intention } \\ \text { H2b } & \text { : Effort Expectancy berpengaruh positif dan signifikan terhadap User Satisfaction } \\ \text { H3a } & \text { : System Quality berpengaruh postif dan signifikan terhadap Behavioral Intention } \\ \text { H3b } & \text { : System Quality berpengaruh postif dan signifikan terhadap User Satisfaction } \\ \text { H4a } & \text { : Social Quality berpengaruh postif dan signifikan terhadap Behavioral Intention } \\ \text { H4b } & \text { : Social Quality berpengaruh postif dan signifikan terhadap User Satisfaction } \\ \text { H5a } & \text { : Behavioral Intention berpengaruh postif dan signifikan terhadap Use Behaviour } \\ \text { H5b } & \text { : Behavioral Intention berpengaruh postif dan signifikan terhadap Net Benefit } \\ \text { H6 } & \text { : User Satisfaction berpengaruh positif dan signifikan terhadap Behavioral Intention } \\ \text { H7 } & \text { : User Satisfaction berpengaruh postif dan signifikan terhadap Net Benefit }\end{array}$

\subsection{Model Struktural}

Pada Gambar 2 menunjukan research model yang telah dibangun menggunakan SmartPLS 3.2.7. Terdapat 8 variabel atau disebut sebagai konstruk dimana masing-masing variabel memiliki masing-masing indikator untuk melakukan pengukuran. Penelitian ini menggunakan indikator-indikator yang direfleksikan sesuai dengan variabel yang akan diukur. Hal ini ditandai dengan arah panah konstruk menuju ke indikator. Konstruk-konstruk yang dimaksud beserta indikatornya adalah sebagai berikut.

1. Konstruk Performance Quality memiliki 4 buah indikator yaitu PQ1, PQ2, PQ3, dan PQ4.

2. Konstruk Effort Expectancy memiliki 3 buah indikator yaitu EE1, EE2, dan EE3.

3. Konstruk System Quality memiliki 4 indikator yaitu SyQ1, SyQ2, SyQ3, dan SyQ4.

4. Konstruk Social Quality memiliki 3 buah indikator yaitu SoQ1, SoQ2, dan SoQ3.

5. Konstruk Behavioral Intention memiliki 3 buah indikator yaitu BI1, BI 2, dan BI3.

6. Konstruk User Satisfaction memiliki 2 buah indikator yaitu US1 dan US 2.

7. Konstruk Use Behaviour memiliki 2 buah indikator yaitu UB1 dan UB2.

8. Konstruk Net Benefit memiliki 4 buah indikator yaitu NB1, NB2, NB3, dan NB4.

Research model diimplementasikan ke dalam SmartPLS 3.2.7 dan melampirkan hasil kuisioner dalam bentuk file .csv, kemudiandilakukan perhitungan menggunakan PLS Algorithm. PLS (Partial Least Square) adalah suatu metode untuk penciptaan dan pembangunan model dengan pendekatan yang berorientasi pada prediksi. PLS memiliki asumsi data penelitian bebas distribusi (Distribution Free), artinya data penelitian tidak mengacu pada salah satu distribusi tertentu (misalnya distribusi normal)[9]. Perhitungan ini dilakukan untuk mengetahui hubungan antar masing-masing konstruk dan indikator yang mendeskripsikan konstruk tersebut. Setelah dihitung menggunakan PLS Algorithm akan dihasilkan nilai-nilai yang menunjukan parameter pengukuran hubungan variabel, nilai validitas dan reliabilitas indikator dan hasil hipotesis yang telah disusun sebelumnya. 


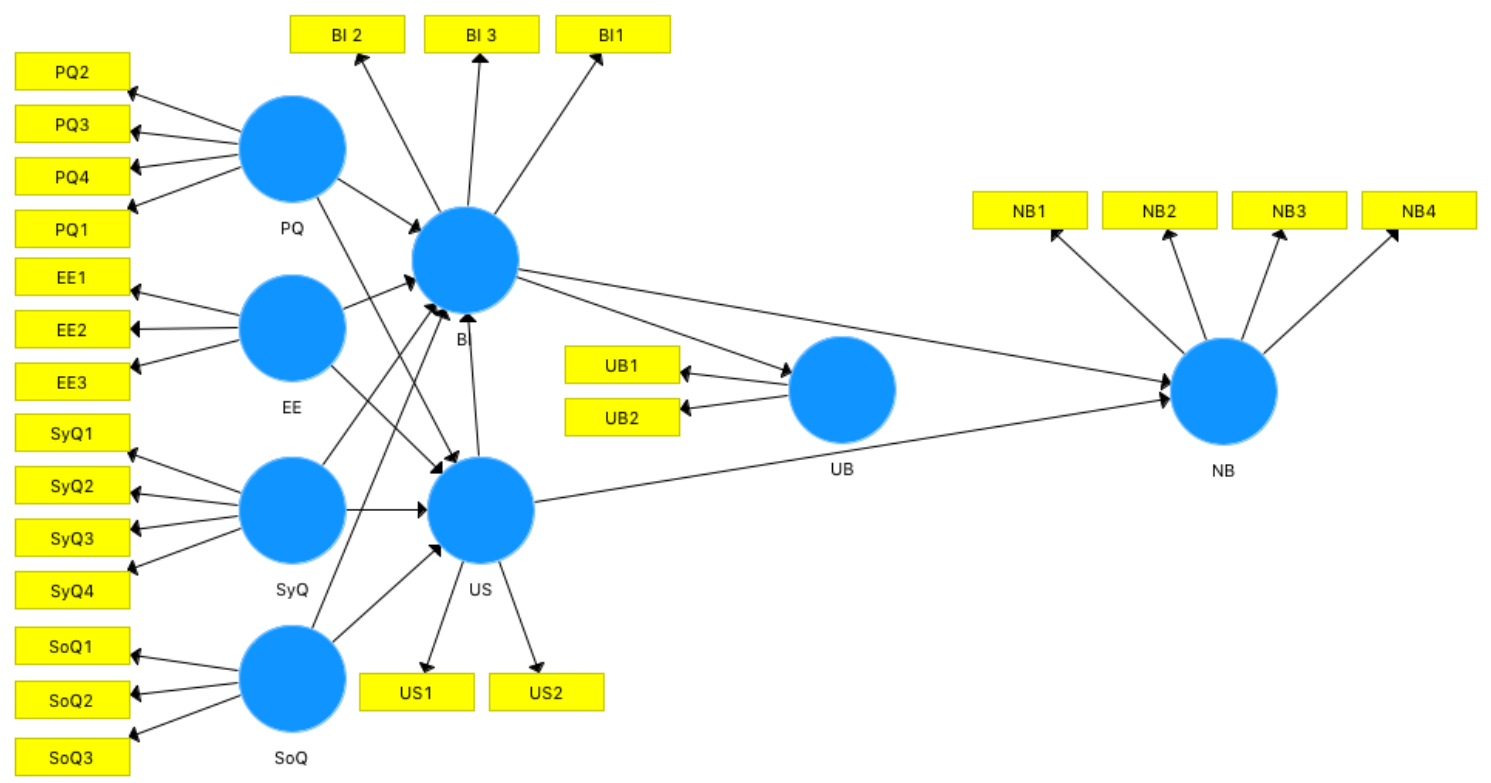

Gambar 2 Model Struktural

\subsection{Model Pengukuran Reflektif}

Langkah pertama dalam analisis data menggunakan PLS adalah evaluasi model pengukuran seperti pada Gambar 3. Evaluasi model pengukuran yang dilakukan adalah untuk konstruk yang bersifat reflektif. Evaluasi dilakukan berfokus pada validitas dan reliabilitas indikator-indikator yang digunakan. Pengukuran dalam evaluasi model reflektif yang dilakukan melalui konsistensi internal (Cronbach's Alpha dan reliabilitas gabungan), validitas konvergen (reliabilitas indikator dan Average Variance Extracted/AVE), dan validitas diskriminan.

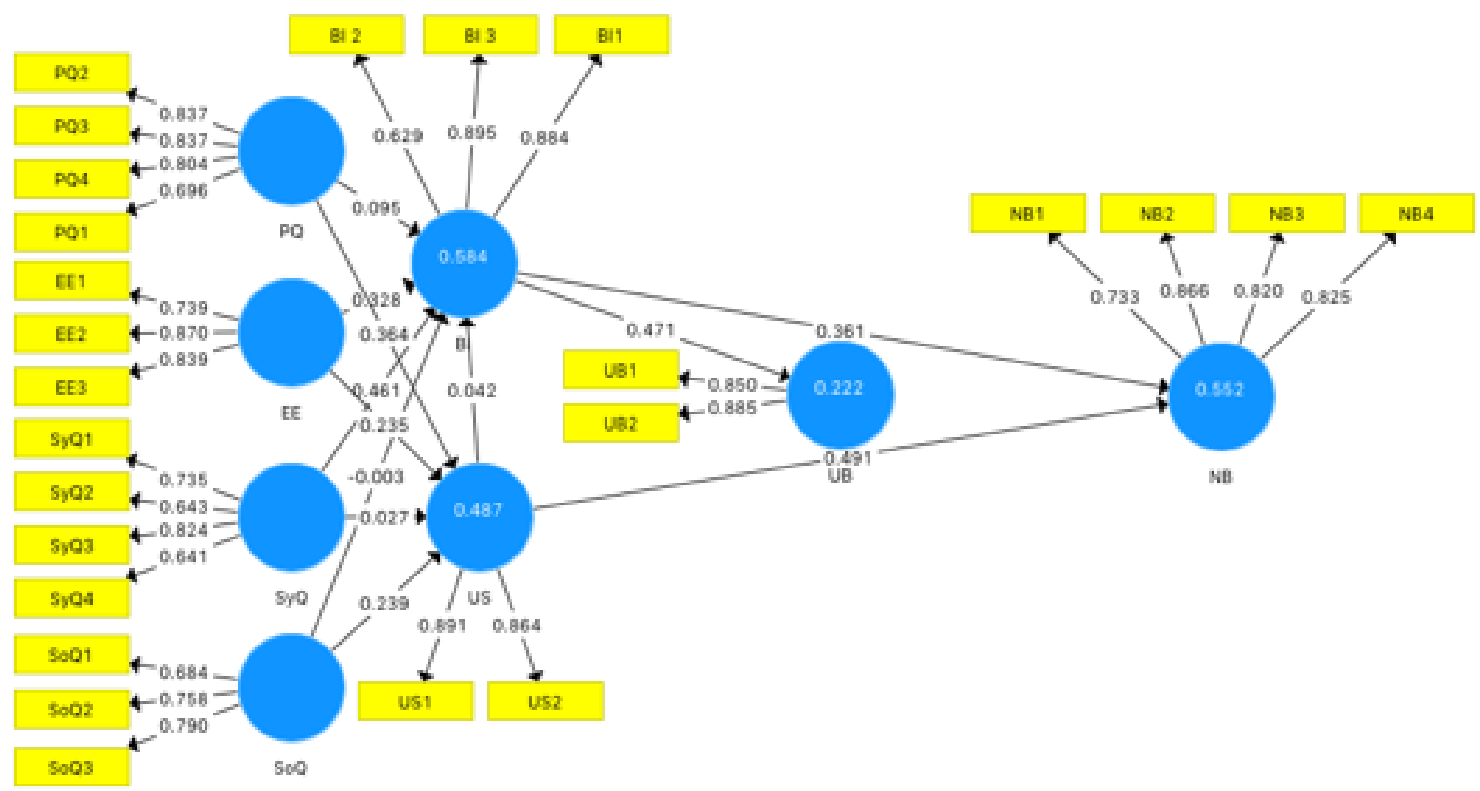

Gambar 3 Hasil Perhitungan Research Model 
1. Konsistensi Internal

Konsistensi internal biasanya diukur menggunakan Cornbach's Alpha, Nilai Cronbach's Alpha dianggap bersifat sensitif terhadap nilai item dalam skala yang digunakan dan mempunyai kecenderungan untuk memberikan penilaian lebih rendah pada konsistensi internal. Untuk mengatasi permasalahan ini maka akan digunakan juga pendekatan lain untuk menilai konsistensi internal yaitu dengan realibitas gabungan (composite reliability). Nilai konsistensi internal berkisar antara $0-1$, dimana makin tinggi nilai konsistensi internalnya maka makin tinggi tingkat reliabilitas alat ukurnya. Nilai konsistensi minimal yang harus dipenuhi untuk batasan reliabel yang akan digunakan dalam penelitian ini adalah $0,6-0,7$ [10]. Hasil perolehan untuk nilai konsistensi internal dapat dilihat pada Tabel 1. Dari Tabel 1, dapat dilihat bahwa alat ukur untuk model penelitian memenuhi kisaran minimal yaitu $0,6-0,7$, sehingga dapat dikatakan bahwa indikator pengukuran dalam penelitian memiliki tingkat reliabilitas yang baik.

Tabel 1 Konsistensi Internal

\begin{tabular}{|l|c|c|}
\hline Konstruk/Variabel & Cronbach's Alpha & Composite Reliability \\
\hline Performance Quality & 0,805 & 0,873 \\
\hline Effort Expectancy & 0,759 & 0,858 \\
\hline System Quality & 0,683 & 0,805 \\
\hline Social Quality & 0,604 & 0,789 \\
\hline Behavioral Intention & 0,743 & 0,850 \\
\hline User Satisfaction & 0,703 & 0,870 \\
\hline Use Behaviour & 0,673 & 0,859 \\
\hline Net Benefit & 0,827 & 0,886 \\
\hline
\end{tabular}

2. Validitas Konvergen

Validitas konvergen adalah ukuran yang menunjukan sejauh mana sebuah indikator berkorelasi positif terhadap indikator lain pada konstruk yang sama. Indikator-indikator dari konstruk harus konvergen atau memiliki berbagai varians dengan proporsi yang tinggi. Nilai validitas konvergen diukuur dengan menggunakan Average Variance Extracted (AVE). Nilai AVE sebesar 0,5 atau lebih menunjukan bahwa konstruk menjelaskan lebih dari separuh varians memang berasal dari indikatornya. Nilai AVE yang kurang dari 0,5 menunjukan bahwa lebih banyak varians tidak berasal dari konstruknya [10]. Hasil nilai AVE yang diperoleh dari perhitungan dapat dilihat pada Tabel 2. Melihat hasil nilai AVE yang diperoleh menunjukan bahwa konstruk mampu menjelaskan varians yang berasal dari indikatornya. Hal ini diperoleh dengan melihat nilai AVE yang memiliki nilai lebih dari 0,5 untuk setiap konstruk yang membangun model penelitian.

Tabel 2 Validitas Konvergen

\begin{tabular}{|l|l|}
\hline \multicolumn{1}{|c|}{ Konstruk/Variabel } & AVE \\
\hline Performance Quality & 0,633 \\
\hline Effort Expectancy & 0,669 \\
\hline System Quality & 0,511 \\
\hline Social Quality & 0,556 \\
\hline Behavioral Intention & 0,659 \\
\hline User Satisfaction & 0,771 \\
\hline Use Behaviour & 0,753 \\
\hline
\end{tabular}




\begin{tabular}{|l|c|}
\hline Net Benefit & 0,660 \\
\hline
\end{tabular}

3. Validitas Diskriminan

Validitas diskriminan merupakan ukuran yang menunjukan bahwa sebuah konstruk berbeda dengan konstruk lain. Selain itu, validitas diskriminan menunjukan mengenai keunikan sebuah konstruk dalam menangkap sebuah fenomena yang tidak dapat ditangkap oleh konstruk lainnya. Validitas diksriminan untuk indikator disebut dengan cross loading. Nilai cross loading untuk suatu konstruk, misalnya A, harus lebih besar dari nilai cross loading ke konstruk lainnya, misalnya B [10]. Nilai cross loading dari model penelitian yang diajukan ditunjukan pada Tabel 3. Dilihat dari hasil yang diperoleh, pada nilai cross loading indikator terhadap konstruknya lebih besar dibandingkan ke konstruk lainnya.

Tabel 3. Cross Loading

\begin{tabular}{|c|c|c|c|c|c|c|c|c|}
\hline & PQ & EE & SyQ & SoQ & BI & US & UB & NB \\
\hline PQ1 & 0,696 & 0,395 & 0,472 & 0,425 & 0,415 & 0,578 & 0,397 & 0,496 \\
\hline PQ2 & 0,837 & 0,296 & 0,663 & 0,550 & 0,462 & 0,450 & 0,502 & 0,570 \\
\hline PQ3 & 0,837 & 0,391 & 0,630 & 0,431 & 0,566 & 0,531 & 0,461 & 0,569 \\
\hline PQ4 & 0,804 & 0,252 & 0,671 & 0,523 & 0,489 & 0,424 & 0,609 & 0,608 \\
\hline EE1 & 0,304 & 0,739 & 0,286 & 0,262 & 0,401 & 0,166 & 0,192 & 0,243 \\
\hline EE2 & 0,343 & 0,870 & 0,370 & 0,340 & 0,469 & 0,457 & 0,263 & 0,353 \\
\hline EE3 & 0,387 & 0,839 & 0,336 & 0,193 & 0,527 & 0,471 & 0,098 & 0,393 \\
\hline SyQ1 & 0,549 & 0,265 & 0,735 & 0,473 & 0,419 & 0,320 & 0,541 & 0,478 \\
\hline SyQ2 & 0,446 & 0,492 & 0,643 & 0,357 & 0,478 & 0,542 & 0,352 & 0,475 \\
\hline SyQ3 & 0,698 & 0,274 & 0,824 & 0,427 & 0,625 & 0,388 & 0,492 & 0,609 \\
\hline SyQ4 & 0,468 & 0,043 & 0,641 & 0,502 & 0,396 & 0,241 & 0,537 & 0,406 \\
\hline SoQ1 & 0,467 & 0,054 & 0,582 & 0,684 & 0,373 & 0,270 & 0,608 & 0,376 \\
\hline SoQ2 & 0,442 & 0,331 & 0,357 & 0,758 & 0,338 & 0,393 & 0,391 & 0,302 \\
\hline SoQ3 & 0,450 & 0,294 & 0,434 & 0,790 & 0,328 & 0,530 & 0,450 & 0,383 \\
\hline BI1 & 0,591 & 0,470 & 0,602 & 0,402 & 0,884 & 0,492 & 0,450 & 0,598 \\
\hline BI2 & 0,197 & 0,532 & 0,302 & 0,153 & 0,629 & 0,148 & 0,180 & 0,225 \\
\hline BI3 & 0,594 & 0,467 & 0,689 & 0,483 & 0,895 & 0,499 & 0,448 & 0,571 \\
\hline US1 & 0,591 & 0,382 & 0,560 & 0,577 & 0,479 & 0,891 & 0,446 & 0,598 \\
\hline US2 & 0,510 & 0,459 & 0,388 & 0,378 & 0,409 & 0,864 & 0,369 & 0,586 \\
\hline UB1 & 0,565 & 0,094 & 0,563 & 0,585 & 0,383 & 0,400 & 0,850 & 0,433 \\
\hline UB2 & 0,509 & 0,274 & 0,576 & 0,520 & 0,433 & 0,409 & 0,885 & 0,541 \\
\hline NB1 & 0,683 & 0,168 & 0,643 & 0,475 & 0,502 & 0,451 & 0,572 & 0,733 \\
\hline NB2 & 0,612 & 0,377 & 0,580 & 0,381 & 0,526 & 0,633 & 0,417 & 0,866 \\
\hline NB3 & 0,475 & 0,415 & 0,509 & 0,348 & 0,461 & 0,546 & 0,405 & 0,820 \\
\hline NB4 & 0,531 & 0,372 & 0,559 & 0,344 & 0,497 & 0,548 & 0,459 & 0,825 \\
\hline
\end{tabular}

\subsection{Pengujian Hipotesis}

Langkah terakhir adalah menentukan diterima atau tidaknya hipotesis yang telah diajukan. Untuk mengetahui hal tersebut, dapat dilakukan dengan membandingkan nilai $t_{\text {hitung }}$ dengan $t_{\text {tabel. }}$. Nilai $t_{\text {tabel }}$ diperoleh berdasarkan tabel distribusi student- $t^{1}$. Sebuah hipotesis dinyatakan diterima apabila $t_{\text {hitung }}>t_{\text {tabel }}[10]$. Hasil pengujian hipotesis menggunakan uji $t$ dapat dilihat pada Tabel 4. 
Tabel 4. Pengujian Hipotesis

\begin{tabular}{|l|l|l|}
\hline \multicolumn{1}{|c|}{ Jalur } & $\mathbf{t}_{\text {hitung }}$ & $\mathbf{t}_{\text {tabel }}$ \\
\hline $\mathrm{PQ} \rightarrow \mathrm{BI}$ & 0,654 & 1,98 \\
\hline $\mathrm{PQ} \rightarrow \mathrm{US}$ & 2,166 & 1,98 \\
\hline $\mathrm{EE} \rightarrow$ BI & 2,947 & 1,98 \\
\hline $\mathrm{EE} \rightarrow$ US & 2,127 & 1,98 \\
\hline $\mathrm{SyQ} \rightarrow \mathrm{BI}$ & 3,186 & 1,98 \\
\hline SyQ $\rightarrow$ US & 0,154 & 1,98 \\
\hline $\mathrm{SoQ} \rightarrow \mathrm{BI}$ & 0,035 & 1,98 \\
\hline $\mathrm{SoQ} \rightarrow \mathrm{US}$ & 1,752 & 1,98 \\
\hline $\mathrm{BI} \rightarrow \mathrm{UB}$ & 4,534 & 1,98 \\
\hline $\mathrm{BI} \rightarrow \mathrm{NB}$ & 4,153 & 1,98 \\
\hline $\mathrm{US} \rightarrow \mathrm{BI}$ & 0,313 & 1,98 \\
\hline $\mathrm{US} \rightarrow \mathrm{NB}$ & 4,610 & 1,98 \\
\hline
\end{tabular}

a. H1a : Performance Quality berpengaruh positif dan signifikan terhadap Behavioral Intention

Hipotesis diatas ditolak karena $t_{\text {hitung }}<$ dari $t_{\text {tabel. }}$. Manfaat e-learning STIKOM Bali tidak memiliki pengaruh positif dan signifikan terhadap niat mahasiswa untuk melakukan perilaku ketika menggunakan e-learning. Hal mungkin terjadi dikarenakan oleh fakta perkuliahan STIKOM Bali yang mewajibkan mahasiswanya menggunakan e-learning. Sehingga, walaupun e-learning memberikan manfaat yang baik bagi perkuliahan mahasiswa, mahasiswa harus tetap atau diwajibkan untuk mengakses e-learning dalam perkuliahan. Melihat dari jawaban responden, mahasiswa cenderung menggunakan elearning hanya ketika perkuliahan berlangsung, melihat tugas ataupun materi.

b. H1b : Performance Quality berpengaruh positif dan signifikan terhadap User Satisfaction

Hipotesis diatas diterima karena $\mathrm{t}_{\text {hitung }}>$ dari $\mathrm{t}_{\text {tabel. }}$. Hal ini berarti bahwa manfaat elearning memberikan pengaruh positif atau berpengaruh secara signifikan terhadap kepuasan bagi penggunanya yaitu mahasiswa. Kepuasan pengguna terutama dalam hal kebutuhan materi dan tugas serta quiz yang diberikan dosen dapat difasilitasi oleh elearning yang digunakan, sehingga kinerja mahasiswa ketika mengikuti perkuliahan menjadi sangat efektif.

c. H2a : Effort Expectancy berpengaruh postif dan signifikan terhadap Behavioral Intention

Hipotesis diatas diterima karena $\mathrm{t}_{\text {hitung }}>$ dari $\mathrm{tt}_{\mathrm{abel}}$. Hal ini berarti bahwa kemudahan fasilitas e-learning memberikan pengaruh positif atau berpengaruh secara signifikan terhadap niat mahasiswa untuk melakukan suatu perilaku penggunaan terhadap elearning. Kemudahan penggunaan e-learning menjadi salah satu keunggulan yang ditawarkan oleh e-learning STIKOM Bali. Sistem e-learning yang mudah digunakan menjadikan niat mahasiswa ketika menggunakan e-learning cenderung ke arah yang lebih positif untuk mendukung proses perkuliahan mereka.

d. H2b : Effort Expectancy berpengaruh positif dan signifikan terhadap User Satisfaction

Hipotesis diatas diterima karena $t_{\text {hitung }}>$ dari $t_{\text {tabel. }}$. Hal ini berarti bahwa kemudahan fasilitas e-learning memberikan pengaruh positif atau berpengaruh secara signifikan terhadap kepuasaan pengguna terhadap e-learning. Kemudahan penggunaan e-learning menjadi sebab kepuasan pengguna ketika menggunakan e-learning. Semakin mudah e- 
learning digunakan maka usaha pengguna untuk memahami sistem juga semakin mudah.

e. H3a : System Quality berpengaruh postif dan signifikan terhadap Behavioral Intention

Hipotesis diatas diterima karena $t_{\text {hitung }}>$ dari $t_{\text {tabel. }}$. Hal ini berarti bahwa karakteristik kualitas dari e-learning memberikan pengaruh positif atau berpengaruh secara signifikan terhadap niat mahasiswa untuk melakukan suatu perilaku penggunaan terhadap elearning. Kualitas e-learning dalam memberikan informasi tentang pelaksanaan perkuliahan menyebabkan mahasiswa ingin atau berniat untuk menimbulkan perilaku berupa akses e-learning.

f. H3b : System Quality berpengaruh postif dan signifikan terhadap User Satisfaction

Hipotesis diatas ditolak karena $t_{\text {hitung }}<$ dari $t_{\text {tabel. }}$ Karakteristik kualitas e-learning STIKOM Bali tidak memiliki pengaruh positif dan signifikan terhadap kepuasaan pengguna e-learning. Kualitas sistem tidak dapat digunakan untuk mengukur kepuasan pengguna. Hal ini dibuktikan dengan baik tidaknya kualitas e-learning yang digunakan, mahasiswa tetap harus menggunakan fasilitas e-learning yang tersedia untuk menunjang perkuliahan.

g. H4a : Social Quality berpengaruh postif dan signifikan terhadap Behavioral Intention

Hipotesis diatas ditolak karena $t_{\text {hitung }}<$ dari $t_{\text {tabel }}$. Variabel keinginan pengguna untuk menggunakan e-learning STIKOM Bali tidak memiliki pengaruh positif dan signifikan terhadap niat mahasiswa untuk melakukan suatu perilaku penggunaan terhadap elearning. Niat pengguna ketika menggunakan e-learning bukan berasal dari pengaruh orang sekitar seperti rekan mahasiswa. Namun, kembali lagi bahwa, penggunaa elearning merupakan suatu kewajiban bagi mahasiswa untuk menunjang perkuliahan mereka.

h. H4b : Social Quality berpengaruh postif dan signifikan terhadap User Satisfaction

Hipotesis diatas ditolak karena $t_{\text {hitung }}<$ dari $t_{\text {tabel }}$. Karakteristik kualitas e-learning STIKOM Bali tidak memiliki pengaruh positif dan signifikan terhadap kepuasaan pengguna e-learning. Sama seperti pada hipotesis sebelumnya bahwa penggunaan elearning menjadi suatu kewajiban bagi pengguna, sehingga social quality bukan menjadi parameter untuk meningkatkan kepuasan pengguna ketika menggunakan e-learning.

i. H5a : Behavioral Intention berpengaruh postif dan signifikan terhadap Use Behaviour

Hipotesis diatas diterima karena $t_{\text {hitung }}>$ dari $t_{\text {tabel. }}$. Hal ini berarti bahwa niat mahasiswa untuk menggunakan e-learning memberikan pengaruh positif atau berpengaruh secara signifikan terhadap perilaku mahasiswa ketika menggunakan e-learning. Niat mahasiswa menggunakan e-learning mendukung perilaku yang akan dilakukan oleh mahasiswa ketika menggunakan e-learning.

j. H5b : Behavioral Intention berpengaruh postif dan signifikan terhadap Net Benefit

Hipotesis diatas diterima karena $t_{\text {hitung }}>$ dari $t_{\text {tabel. }}$. Hal ini berarti bahwa niat mahasiswa untuk menggunakan e-learning memberikan pengaruh positif atau berpengaruh secara signifikan terhadap dampak kesuksesan implementasi e-learning. Niat mahasiswa menggunakan e-learning menjadi faktor kesuksesan penerapan e-learning untuk mendukung perkuliahan mahasiswa.

k. H6 : User Satisfaction berpengaruh positif dan signifikan terhadap Behavioral Intention

Hipotesis diatas ditolak karena $t_{\text {hitung }}<$ dari $t_{\text {tabel }}$. Karakteristik kualitas e-learning STIKOM Bali tidak memiliki pengaruh positif dan signifikan terhadap kepuasaan 
pengguna e-learning. Kepuasan pengguna bukan merupakan faktor pendukung untuk mahasiswa memiliki niat untuk selalu atau setiap hari mengakses e-learning. E-learning hanya diakses mahasiswa ketika perkuliahan, akses materi perkuliahan ataupun tugas.

1. H7 : User Satisfaction berpengaruh positif dan signifikan terhadap Net Benefit

Hipotesis diatas diterima karena $t_{\text {hitung }}>$ dari $t_{\text {tabel. }}$ Hal ini berarti bahwa kepuasan penggunaan e-learning memberikan pengaruh positif atau berpengaruh secara signifikan terhadap dampak kesuksesan implementasi e-learning. Kepuasan pengguna ketika menggunakan e-learning menunjukan bahwa e-learning efektif mendukung pelaksanaan perkuliahan mahasiswa. Dimulai dari kemudahan kemudahan penggunaan serta manfaat yang diberikan menjadikan penerapan e-learning sukses untuk mendukung perkuliahan mahasiswa.

\section{KESIMPULAN}

Kesimpulan yang diperoleh adalah sebagai berikut.

1. Instrumen penelitian berupa kuisioner yang disebarkan kepada 98 mahasiswa dan terdiri dari indikator-indikator yang memiliki tingkat validitas dan reliabilitas yang baik untuk menggambarkan konstruknya.

2. Manfaat e-learning tidak memiliki pengaruh positif terhadap keinginan atau niat pengguna untuk menggunakan e-learning, mengingat e-learning adalah fasilitas wajib dalam perkuliahan.

3. Kualitas sistem tidak dapat digunakan untuk mengukur kepuasan pengguna, karena baik tidaknya sistem e-learning yag diterapkan mahasiswa tetap harus menggunakan e-learning sebagai penunjang perkuliahan.

4. Pengaruh lingkungan luar tidak memiliki peran untuk mempengaruhi baik niat penggunaan e-learning ataupun kepuasan pengguna. E-learning merupakan fasilitas wajib yang harus diakses mahasiswa untuk memenuhi kebutuhan informasi pekuliahan.

5. Kepuasan terhadap penggunaan e-learning tidak mempengaruhi keinginan pengguna untuk setiap hari mengakses e-learning. Keperluan pengaksesan e-learning hanya digunakan saat mencari informasi perkuliahan.

6. Penerimaan pengguna terhadap penerapan e-learning sebagai bagian dari teknologi pendukung perkuliahan menyebabkan sebuah informasi sukses diterapkan dalam lingkungannya. Hal ini dapat dilihat dari model penelitian yang diajukan menunjukan sebagian besar variabelnya mempengaruhi kesuksesan penerapan e-learning baik secara langsung maupun tidak langsung. Variabel-variabel tersebut adalah performance quality, effort expectancy, system quality, behavioral intention, dan user satisfaction.

\section{SARAN}

Saran yang dapat diberikan setelah melakukan penelitian ini adalah sebagai berikut.

1. Responden dapat juga oleh dosen sebagai pendidik, sehingga evaluasi dapat dilakukan kepada semua pengguna e-learning.

2. Hasil kajian berupa evaluasi ini dapat digunakan sebagai pedoman untuk mengembangkan elearning yang dapat menarik minat pengguna untuk menggunakan sehingga kepuasan pengguna menjadi meningkat. 


\section{DAFTAR PUSTAKA}

[1] E. Hernawati and P. Aji, "Perancangan dan Penerapan Konten e-Learning melalui Learning Management System dalam Meningkatkan Motivasi Belajar," J. Inf. Syst. Eng. Bus. Intel., vol. 2, no. 1, pp. 23-32, 2016.

[2] S. E. Yulianto, "Pengaruh Persepsi Kemudahan dan Persepsi Kemanfaatan Terhadap Pemanfaatan E-Learning dengan Model TAM di SMK Muhammadiyah 3 Yogyakarta," JBTI, vol. 1, no. 1, pp. 44-60, 2011.

[3] S.-M. Hellstén and M. Markova, "The DeLone and McLean Model of Information Systems Success - Original and Updated Models," SIGCHI 2006 Proc., vol. 19, no. 4, pp. 1-5, 2006.

[4] J. F. Arifin and S. Pratolo, "Pengaruh Kualitas Sistem Informasi Keuangan Daerah Terhadap Kepuasan Aparatur Pemerintah Daerah Menggunakan Model DeLone dan McLean," J. Akunt. Investasi Vol. 13 No. 1, vol. 13, no. 1, pp. 28-34, 2012.

[5] T. Handayani and A. Sunyoto, "Analisis Penerimaan Sistem Informasi Akademik Berbasis Web Mengunakan Technology Acceptance Model ( TAM ) Dan Usability Studi Kasus Pada STTNAS," J. Angkasa, vol. V, no. 1, pp. 63-74, 2013.

[6] H. Agustin and E. Mulyani, "Studi Empiris Penerimaan dan Penggunaan E- Learning System di Kalangan Mahasiswa Akuntansi Fakultas Ekonomi UNP," in Seminar Nasional Aplikasi Teknologi Informasi (SNATi), 2016, pp. 17-22.

[7] R. K. J. Bendi and S. Andayani, "Analisis Perilaku Penggunaan Sistem Informasi Menggunakan Model UTAUT," in Seminar Nasional Teknologi Informasi \& Komunikasi Terapan 2013 (Semantik 2013), 2013, vol. 2013, no. November, pp. 277282.

[8] K. D. P. Novianti, "Model Evaluasi E-learning Menggunakan Integrasi Model D \& M dan UTAUT," in Seminar Nasional Sistem Informasi dan Teknologi Informasi, 2018, pp. 341-345.

[9] A. S. Hussein, "Penelitian Bisnis dan Manajemen Menggunakan Partial Least Squares (PLS ) dengan SmartPLS 3.0," Jur. Manaj. Fak. Ekon. dan Bisnis Univ. Brawiajaya, 2015.

[10] P. I. Santosa, Metode Penelitian Kuantitatif Pengembangan Hipotesis dan Pengujiannya Menggunakan SmartPLS. Yogyakarta: Penerbit Andi, 2018. 